\title{
IDENTIFICATION OF LAYERS PRESENT IN A CONTEMPORARY CERAMIC USING LASER-INDUCED PLASMA SPECTROSCOPY
}

\author{
Celina Luízar Obregón*, Daniel L’hermite ${ }^{2}$
}

\begin{abstract}
In this work, laser-induced plasma spectroscopy was used to identify the elemental composition, at different depths, of a commercial Peruvian ceramic. The IVEA MobiLIBS system and IUMTEK TX1000 system were used, under environmental conditions and 5.6 $\mathrm{mJ}$ of energy, forming craters of approximately $60 \mu \mathrm{m}$ in diameter. To improve accuracy, repetitions of the impact points were performed, accumulating the signals at the same depth. The blue and white pigments that covered it, as well as the matrix paste, were characterized, making different levels of penetration in the material, obtaining their respective elemental composition. This allowed finding the difference between stratigraphic layers, based mainly on the variation of the intensities of Copper, Titanium, Carbon and other characteristic elements of the clays that make up the matrix paste. Contemporary pottery was found to have sequential layers of decoration, engobe and matrix paste.
\end{abstract}

Key words: LIBS, analysis, ceramic, pottery, stratigraphy, pigment

\section{IDENTIFICACIÓN DE LAS CAPAS PRESENTES EN UNA CERÁMICA CONTEMPORÁNEA UTILIZANDO ESPECTROSCOPÍA DE PLASMA INDUCIDO POR ABLACIÓN LÁSER}

\begin{abstract}
RESUMEN
En este trabajo se utilizó la espectroscopía de plasma inducido por láser para identificar la composición elemental, a diferentes profundidades, de una cerámica comercial peruana. Se usaron los sistemas LIBS MobiLIBS de IVEA y TX1000 de IUMTEK con un láser pulsado, energía optimizada a $5.6 \mathrm{~mJ}$, bajo condiciones ambientales, formando cráteres de aproximadamente $60 \mu \mathrm{m}$ de diámetro. Para mejorar la exactitud, se realizaron repeticiones de los puntos de impacto, acumulando las señales de igual profundidad. Se caracterizaron

\footnotetext{
${ }^{1 *}$ Chemistry Academic Department, Faculty of Sciences, Universidad Nacional de San Antonio Abad del Cusco, De la Cultura Av. 733, Perú; email: Celina.luizar@unsaac.edu.pe

${ }^{2}$ Université Paris-Saclay, CEA, Service d'Études Analytiques et de Réactivité des Surfaces, 91191, Gif-sur-Yvette, France.
} 
los pigmentos azul y blanco que la recubrían, así como la pasta matriz, haciendo diferentes niveles de penetración en el material, obteniéndose su respectiva composición elemental. Esto permitió encontrar la diferencia entre capas estratigráficas, basadas principalmente en la variación de las intensidades de cobre, titanio, carbono y otros elementos característicos de las arcillas que constituyen la pasta matriz. Se encontró que la cerámica contemporánea presentaba estratos secuenciales de pintado de color, engobe y pasta matriz.

Palabras clave: LIBS, análisis, cerámica, estratigrafía, pigmento

\section{INTRODUCTION}

For the physicochemical study of tangible cultural heritage, there are different techniques for non-destructive or minimally invasive surface elemental analysis such as Fourier transform infrared spectroscopy (FTIR) ${ }^{1}$, Raman spectroscopy ${ }^{2,3}$, electron microscopy (SEM or TEM), $\mathrm{X}$-ray fluorescence $(\mathrm{XRF})$ and $\mathrm{X}$-ray diffraction $(\mathrm{XRD})^{4}$, nuclear magnetic resonance (NMR) among others. However, none of them perform elemental analysis through the different layers of the material in a minimally invasive fast way and without sample preparation as the Laser Induced Breakdown Ablation Spectroscopy (LIBS) does ${ }^{4-10}$.

LIBS is based on the generation of a plasma composed of the ablated matter as a consequence of the impact of a laser pulse on the surface of the study material ${ }^{11}$. The plasma contains chemical elements of the material. The excited neutral species and ions have characteristic emission energies that, during their decay, can be detected.

The sensitivity of the method depends, among others, on the chemical element, the parameters of detection, the environmental conditions, and the selection of the area to be analyzed in the sample. $^{12}$

There are several free-access spectroscopic databases for the qualitative verification of a chemical element. The most common and complete is the National Institute of Standards and Technology (NIST) ${ }^{13}$ one, which is also used by the LIBS software for the processing of LIBS spectra.

Among the advantages of LIBS in the study of tangible cultural heritage materials is that it does not require sample preparation, its simplicity in the analysis procedure, which can be insitu, its micro-destructive character by generating a micro crater of even $60 \mu \mathrm{m}$ (something imperceptible to human eye), the ability to analyze several chemical elements quickly and simultaneously such as $\mathrm{Na}, \mathrm{Mg}, \mathrm{Al}, \mathrm{Si}, \mathrm{P}, \mathrm{S}, \mathrm{K}, \mathrm{Ca}, \mathrm{Ti}, \mathrm{Ba}$ and others that make up the clays and the pigments that cover them, as well as the identification of light elements like $\mathrm{C}, \mathrm{N}$ and $\mathrm{O}$, and even rare elements like lithium.

A good part of the studies of Peruvian archaeological ceramics and pottery (Inca and pre-Inca) as well as the colonial era, is based on the observation of archaeologist who characterizes 
the ceramic based on the form, decoration, finish, and use. Also, there are studies related to elemental composition determination of clays, pigments, and raw material which used destructive or minimally invasive analysis.

In the literature, we did not find spectroscopic studies of the potter's elaboration process, neither spectroscopic characterization of sequential stages as engobe application, glaze, decoration, enameled coloration, and final painting of Peruvian archaeological pottery. This work aims to find indications of how a contemporary commercial ceramic would have been elaborated, based on LIBS's stratigraphic analysis, to have the basis for subsequent studies with Peruvian archaeological pieces.

\section{EXPERIMENTAL PART}

\section{Contemporary Peruvian Commercial Pottery Sample}

A contemporary decorative commercial ceramic piece with the shape of a concave plate (Figure 1), diameter of $5.5 \mathrm{~cm}$, was selected because it has a blue coating finish on the front face that is easily differentiated from the matrix paste. Five points of analysis were selected for each color (Figure 2): blue (b1-b5), white (w1-w5), base (bs1-bs5, front side) and the master paste (back).

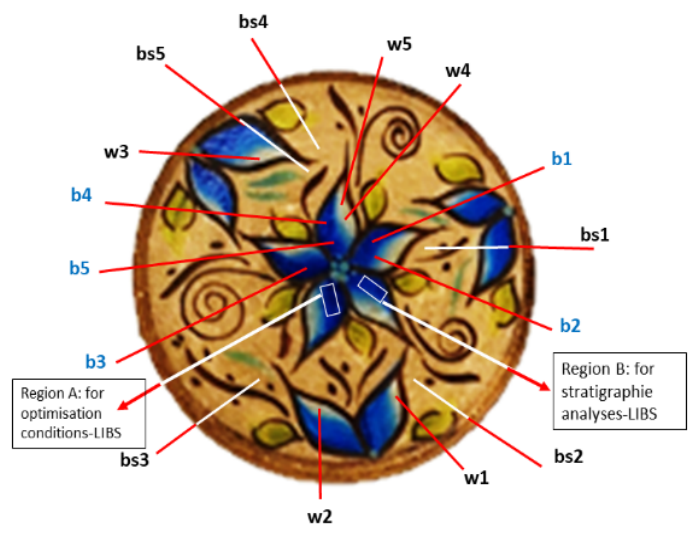

Figure 1. Areas and points of analysis: $b=$ blue, $w=$ white, $b s=$ commercial ceramic base.

In the blue area, 3 type of tests were carried out: 1) identification of the elements, especially $\mathrm{Cu}$ and $\mathrm{Ti}$; 2) optimization of the LIBS analysis parameters for detection of $\mathrm{Cu}$; and 3) differentiation of stratigraphic layers based on elemental composition. 


\section{Laser Induced Ablation Spectrometry}

A MOBILIBS (IVEA Co.) ${ }^{14}$ laser-induced ablation spectrometer was used, with a pulsed Nd: YAG laser at $266 \mathrm{~nm}$, a maximum energy available of $10 \mathrm{~mJ}$, a repetition rate of $20 \mathrm{~Hz}$, a pulse duration of approximately $4 \mathrm{~ns}$. The embedded spectrometer is the ANDOR Mechelle covering 200 to $900 \mathrm{~nm}$ with an ICCD ANDOR Istar detector. The second system was a TX1000 (IUMTEK) ${ }^{15}$ laser-induced ablation spectrometer, with a pulsed Nd: YAG laser at $1064 \mathrm{~nm}$, maximum energy available of $30 \mathrm{~mJ}$, a repetition rate of $20 \mathrm{~Hz}$, a pulse duration of approximately $10 \mathrm{~ns}$. The embedded spectrometer is the ANDOR Mechelle covering 200 to $980 \mathrm{~nm}$ with an ICCD ANDOR Istar detector. Both systems were previously calibrated with a Hg: Ar lamp (Ocean Optics). All analyzes were performed at environmental conditions, under normal atmosphere.

The AnaLIBS software v.6.3 was used to control the focusing of the laser at the point of impact through an optical system and an automatic XYZ positioning system; to change the experimental parameters for optimization of the signal (laser frequency and energy, delay time, exposure time, gain and others); to acquire the individual spectra; to identify the chemical elements emission lines; and finally, to do some mathematical operation on spectra like sum and average, as well as subtraction of the background.

The depth of the craters was measured using an optical Profilometer (Bruker) with the Vision 64 software v.4.1.

\section{RESULTS AND DISCUSSION}

\section{Identification of $\mathrm{Cu}$ and $\mathrm{Ti}$ in the blue pigment}

To verify the presence of Copper in the blue region, a set of $3 \times 2$ sequential spots (vertical $x$ horizontal in $\mathrm{mm}$ ) spaced by $2 \mathrm{~mm}$ intervals was executed with 10 consecutive shots at each point, making a total of 60 shots. The parameters of detection were: delay time $500 \mathrm{~ns}$, gate 2 $\mu$ s, gain 200. The following lines were identified for $\mathrm{Cu}$ I: $324.75 ; 327.389$, and $515.307 \mathrm{~nm}$ (Figure 2). The most intense is at $324.775 \mathrm{~nm}$. For Titanium, several neighboring lines were identified in the regions of 320 to $230 \mathrm{~nm} ; 497.5$ to $504.5 \mathrm{~nm}$ and 517.2 to $521.3 \mathrm{~nm}$. We have selected the Ti I lines at 517.78 and $519.298 \mathrm{~nm}$.

\section{Optimization of LIBS analysis parameters for qualitative $\mathrm{Cu}$ detection}

The values (Table 1) correspond to the best experimental conditions for analysis in the blue region, which allowed the identification of $\mathrm{Cu}$ lines $(324.75 \mathrm{~nm})$, with a more intense signal, less noise, good S/B ratio, minimal damage to the ceramic surface, and that allowed to differentiate the first ceramic finish coat. 

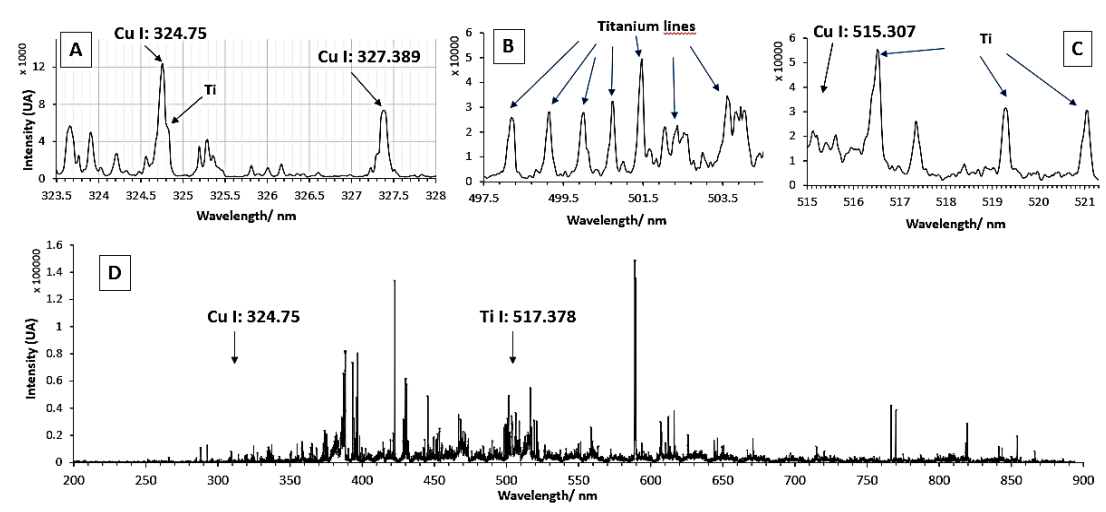

Figure 2. LIBS spectrum of the first layer for the blue pigment in the pottery and the $\mathrm{Cu}$ and $\mathrm{Ti}$ lines for LIBS analysis optimization. A) enlargement for $\mathrm{Cu}$ line; $\mathrm{B}$ and $\mathrm{C}$ ) enlargement for $\mathrm{Ti}$ lines; D) complete LIBS sum spectrum $(200-900 \mathrm{~nm})$.

Subsequently, under these conditions, a 3x2 matrix shots sequence was performed respectively on the blue and white coatings and the matrix paste (on the backside). Then, the sum spectrum of 6 spectra was obtained for each one (Figure 2D). We observed that the blue pigment presented more intensity for $\mathrm{Cu}$, while the white area had more counts for Titanium (Figure 3).

Table 1. LIBS parameters optimized for copper lines (324.75 nm).

\begin{tabular}{|c|c|c|c|c|c|c|c|c|}
\hline \multirow[t]{2}{*}{ Grupo } & \multirow[t]{2}{*}{$\mathrm{N}$} & \multirow[t]{2}{*}{ Media } & \multirow{2}{*}{$\begin{array}{c}\text { Desv. } \\
\text { Estándar }\end{array}$} & \multirow{2}{*}{$\begin{array}{l}\text { Desv. } \\
\text { Error }\end{array}$} & \multicolumn{2}{|c|}{$95 \%$ IC } & \multirow[t]{2}{*}{ Mínimo } & \multirow[t]{2}{*}{ Máximo } \\
\hline & & & & & $\begin{array}{l}\text { Límite } \\
\text { inferior }\end{array}$ & $\begin{array}{l}\text { Límite } \\
\text { superior }\end{array}$ & & \\
\hline Patrón & 4 & 0,0000 & 0,0000 & 0,0000 & 0,0000 & 0,0000 & 0,0000 & 0,0000 \\
\hline Atomizado & 4 & 4,9575 & 0,2351 & 0,1175 & 4,5834 & 5,3316 & 4,6365 & 21,6753 \\
\hline Liofilizado & 4 & 20,1814 & 1,3162 & 0,6581 & 18,0869 & 22,2758 & 18,9487 & 21,6753 \\
\hline Total & 12 & & & & & & & \\
\hline
\end{tabular}

This sequence allows distinguishing the composition of the first layer in the blue facing, the white facing, and the matrix paste (Figure 3). 


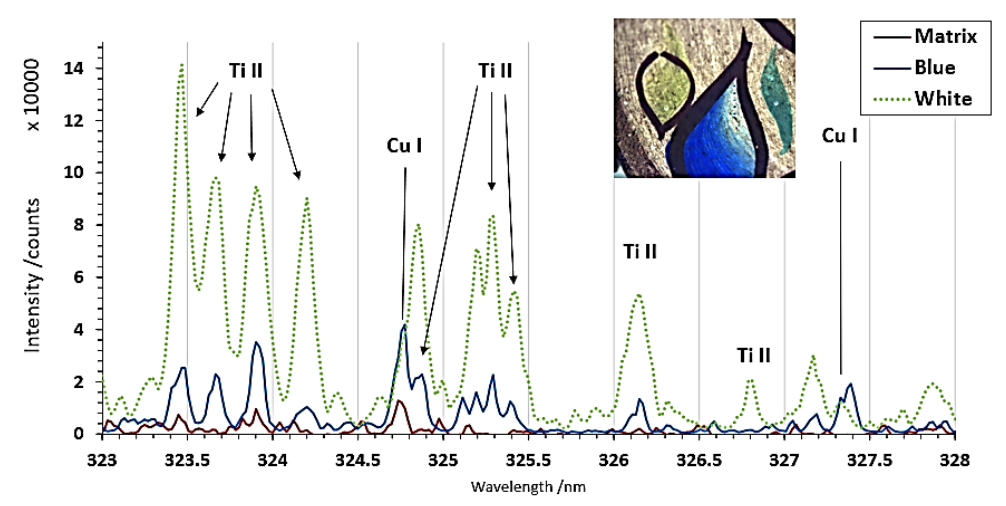

Figure 3. Part of the LIBS spectrum for the first shot on the blue, white and matrix paste (reverse) coatings of the ceramic.

The $\mathrm{Cu}$ I lines are observed at $324.75 \mathrm{~nm}$, but it overlaps partially with the Ti 324.86 line; for this reason, we measure $\mathrm{Cu}$ line intensity by subtracting the Ti line. The results show (Figure 4) that $\mathrm{Cu}$ line intensity decreases against the shot number. At the opposite of Titanium line increase regarding the depth of the crater. The analysis was made over the blue region, but there is probably a white paint layer under the blue layer. That is why we observe the apparition of Ti lines.
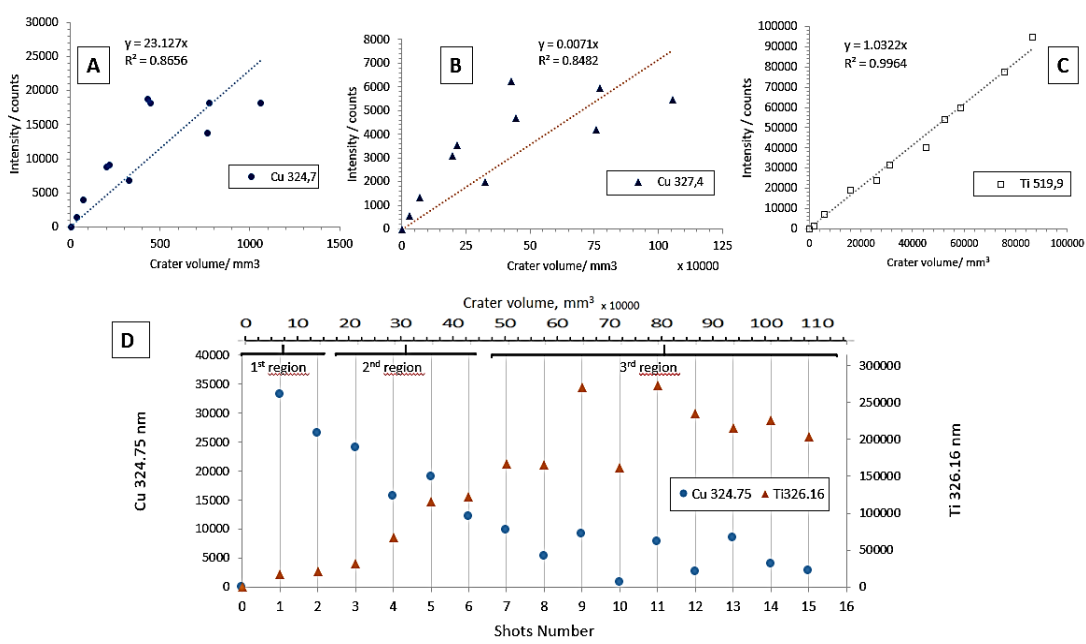

Figure 4. Blue facing: $\mathrm{Cu}$ and $\mathrm{Ti}$ lines varying with the shot number and crater volume. A) and B) Interference of the $\mathrm{Ti}$ on $\mathrm{Cu}$ lines. C) Ti 519.9 without $\mathrm{Cu}$ interference. D) $\mathrm{Cu} 324.75$ without Ti counts. 


\section{Differentiation of stratigraphic layers}

The Figure 4A and B show the accumulated intensities of $\mathrm{Cu}$ lines over the number of shots versus the volume of the crater. Therefore, when we exclude the Ti counts from the $\mathrm{Cu} 324.75$ $\mathrm{nm}$ line, it is possible to identify three regions as we advance in the depth of the crater (Figure 4D). In the first region (first and second shot) $\mathrm{Cu} 324.75$ has the highest number of counts/s, and minor intensities for Ti. The second region (3rd to the 8th shot) has both presence of $\mathrm{Cu}$ and Ti. Probably, the profile of the laser beam (Gaussian) produces this mixture of signal from blue and white pigments, the center of the beam digging more rapidly the sample than the edge of the beam. The third region starts on the 9th shot and goes on constituting the white paint. Here the Ti lines are much more intense than $\mathrm{Cu}$ lines intensities.
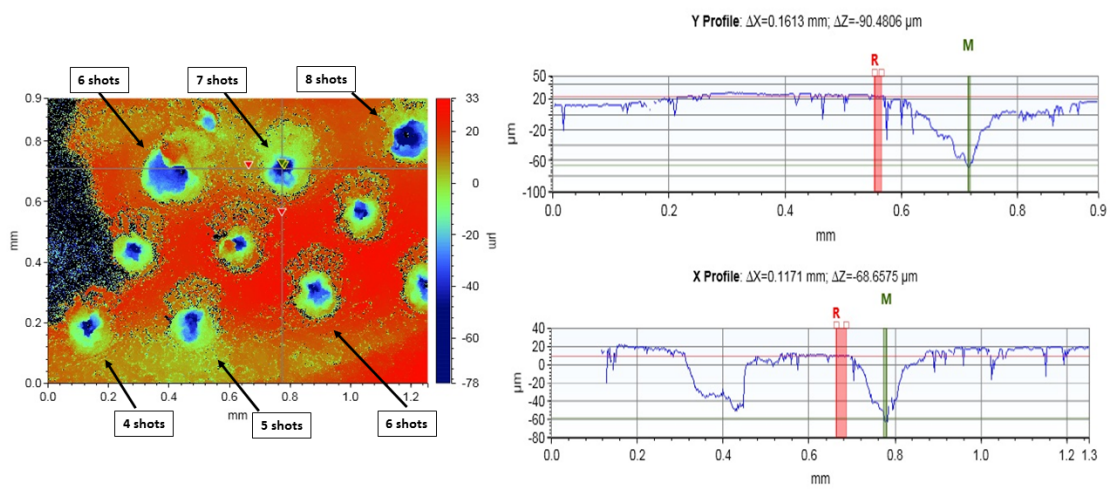

Figure 5. A sequence of craters originated with a laser of $5.6 \mathrm{~mJ}$ of energy. Right: depth measurement (Y profile) of the crater formed with seven shots, and left: craters since four to eight shots in 3 repetitions.

\section{Identification of the composition of the blue pigment}

Among the blue pigments currently marketed, there are Lapis Lazuli $(\mathrm{Na}, \mathrm{Ca})_{4}\left(\mathrm{Al}_{,} \mathrm{SiO}_{4}\right)_{3}\left(\mathrm{SO}_{4}, \mathrm{~S}, \mathrm{Cl}\right)$, Maya Blue (indigo and paliogorskite) rich in $\mathrm{Mg}$ and $\mathrm{Al}$, Apatite $\mathrm{Ca}_{5}\left(\mathrm{PO}_{4}\right)_{3} \mathrm{~F}$, Cobalt blue CoO. $\mathrm{Al}_{2} \mathrm{O}_{3}$, Celurean blue $\mathrm{CoO} . \mathrm{nSnO}_{2}$, Erinite $\mathrm{Ca}_{4}(\mathrm{Al} ; \mathrm{Fe}$ $\left.{ }^{3+} ; \mathrm{Mg} ; \mathrm{Fe}^{2+}\right)_{10} \mathrm{Si}_{12} \mathrm{O}_{35}\left(\mathrm{CO}_{3}\right)(\mathrm{OH})_{12} .12 \mathrm{H}_{2} \mathrm{O}$, Cavansite $\mathrm{Ca}(\mathrm{VO}) \mathrm{Si}_{4} \mathrm{O}_{10} \cdot 4 \mathrm{H}_{2} \mathrm{O}$, and others that do not contain $\mathrm{Cu}$. The LIBS analysis showed that S, F, Co, Sn and V are not detectable, therefore the presence of this group of pigments, as well as $\mathrm{CuSO}_{4}$, was ruled out.

The $\mathrm{Cu}$ common minerals in Peru are malachite $\left(\mathrm{Cu}_{2} \mathrm{CO}_{3}(\mathrm{OH})_{2}\right)$, chrysocolla $\left((\mathrm{Cu}, \mathrm{Al})_{2} \mathrm{H}_{2} \mathrm{Si}_{2} \mathrm{O}_{5}(\mathrm{OH})_{4} \cdot \mathrm{nH}_{2} \mathrm{O}\right)$ and greenish-colored atacamite (crystalline form $\left.\mathrm{Cu}_{2} \mathrm{Cl}(\mathrm{OH})_{3}\right)$, chalcosite $\left(\mathrm{Cu}_{2} \mathrm{~S}\right)$ and covellin $(\mathrm{CuS})$ which have an indigo blue color. And among the blue pigments that contain $\mathrm{Cu}$ and are common, Azurite or Malachite $\mathrm{Cu}_{3}\left(\mathrm{CO}_{3}\right)_{2}(\mathrm{OH})_{2}$, Turquoise $\mathrm{Cu}\left(\mathrm{Al}, \mathrm{Fe}^{3+}\right)_{6}\left(\mathrm{PO}_{4}\right)_{4}(\mathrm{OH})_{8} \cdot 4 \mathrm{H}_{2} \mathrm{O}$, Egyptian Blue $\mathrm{CaCuSi}{ }_{4} \mathrm{O}_{10}$, Han Blue or Chinese Blue $\mathrm{BaCuSi}_{4} \mathrm{O}_{10}$ and Kyanite $\mathrm{Ca}_{2} \mathrm{Cu}_{2} \mathrm{Si}_{3} \mathrm{O}_{8}(\mathrm{OH})_{4}$ were found. Since the intensities of $\mathrm{Ba}$ and $\mathrm{P}$ are too low to be present, it is more likely that the used pigment was Azurite $\mathrm{Cu}_{3}\left(\mathrm{CO}_{3}\right)_{2}(\mathrm{OH})_{2}$, 
since $\mathrm{CaCuSi}_{4} \mathrm{O}_{10}$ and $\mathrm{Ca}_{2} \mathrm{Cu}_{2} \mathrm{Si}_{3} \mathrm{O}_{8}(\mathrm{OH})_{4}$ are less common. Furthermore, the results indicate that the blue pigment seems not to be related to $\mathrm{Ca}$ (Kyanite) or $\mathrm{Al}$ (Chrysocolla), because the line intensities of these two elements in the first layers (Ca 616.2 and Al 394.3 value in the sum spectrum of the first shot of Sum T1) are not more intense than in the matrix paste (values in SumT10).

Furthermore, in the first three layers (paint) no signals were found for S, implying the absence of sulfur compounds, and consequently excluding the presence of ultramarine blue $(\mathrm{Na}, \mathrm{Ca})_{8}\left(\mathrm{AlSiO}_{4}\right)_{6}\left(\mathrm{SO}_{4}, \mathrm{~S}, \mathrm{Cl}\right)_{2}$. Otherwise, LIBS is not very sensitive for Sulfur detection in atmospheric conditions, so the last affirmation is not conclusive.

\section{Exploration of the nature of the ceramic matrix paste}

The total sum of 30 spectra was obtained. The background was removed (Figure 5), the presence of the elements $\mathrm{Na}, \mathrm{Mg}, \mathrm{Al}, \mathrm{Si}, \mathrm{K}, \mathrm{Ca}, \mathrm{Fe}$, Ti and $\mathrm{Mn}$, which are usual components of clays, was interpreted and confirmed.

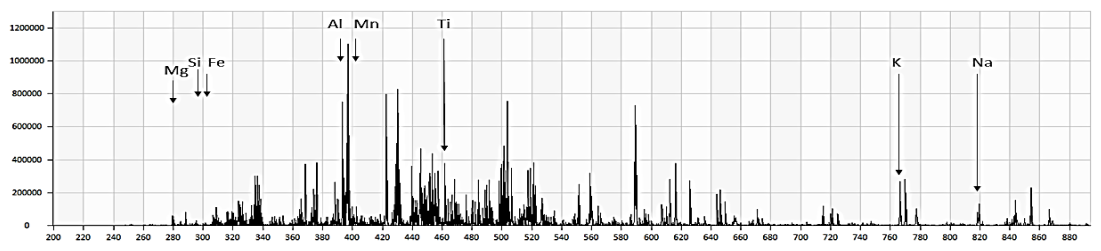

Figure 5. LIBS spectrum of the matrix paste in the ceramic from the total sum spectrum of 30 spectra: 10 shots at the same point with 3 repetitions at different positions.

It was observed that the deeper layers have more intense lines of $\mathrm{Al}(308.2,309.3,394.4$, $396.18 \mathrm{~nm}), \mathrm{Ca}(315.9,393.4,422.7$ and $396.8 \mathrm{~nm}), \mathrm{Mg}(279.5$ and $384.8 \mathrm{~nm}), \mathrm{Na}(330.2$ and $818.4 \mathrm{~nm})$ and $\mathrm{Si}(288.2,390.5$ and $422.7 \mathrm{~nm})$.

\section{Examination of the presence of slipware on the matrix paste}

The lines of C 247.856 and N 877 were analyzed to verify a resin's presence on the topcoat. For the elemental analysis, the LIBS TX1000 system was used, with an energy of $5.6 \mathrm{~mJ}$, in sequential layer-by-layer shots. Spectra from 16 shots at the same depth (4x4 matrix) was averaged. We have repeated this protocol at the same place from one to one hundred level of depths. The process was carried out on the blue (b) and white (w) coating, the unpigmented front surface (var), and the ceramic's back (matrix paste $=$ pst). 


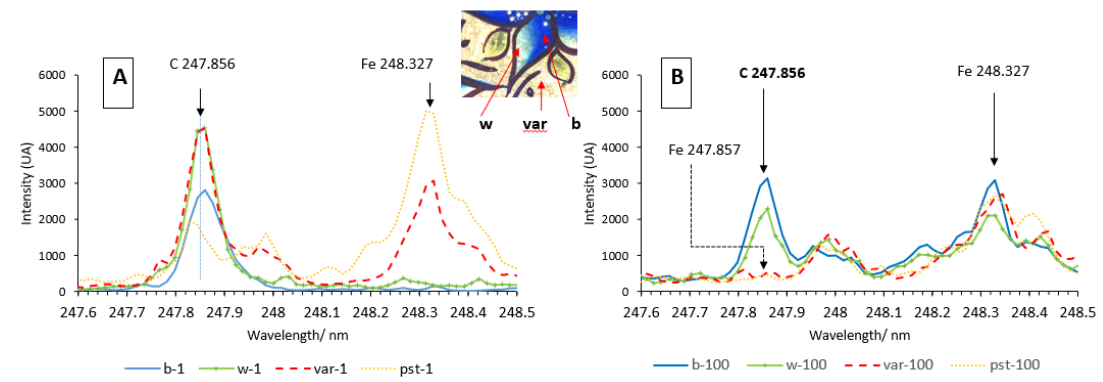

Figure 6. Average LIBS spectra (5.6 mJ) for C 247 line of the blue (b), white (w), unpigmented front surface (var), and matrix paste (pst) coating; A) one shot, and B) 100 shots.

The Fe lines interfere in the qualitative detection of C 247,876 nm (Figure 6). At the first shot (Figure 6A), the spectrum of the matrix paste (pst-1) and the spectrum of the engobe "up side" on front surface (var-1) show the Fe 248.327 line. But the blue (b-1) and white (w-1) covering do not show Fe 248.33 line. These findings allow us to infer that the 247.856 line in b-1 and w-1 corresponds to Carbon and confirms both coatings contain at least one organic compound. When comparing spectra at 100 shots depth (Figure 6B), the C 247.856 line is not detectable on matrix past (pst-100) and engobe (var-100). We conclude that the matrix paste does not have Carbon and that engobe is a thin layer completely drill after 100 laser shots. Therefore, blue and white layer are relatively thick because we detect the Carbon and Iron lines simultaneously. The laser beam profile creates those mixture of signal because the center of the laser drill deeper than the edge of the beam.

On the other hand, these spectra show the $\mathrm{N}$ lines, but it is not clear his origin. It could be from the analyzed material or from the air. To be sure it is necessary to do experiments under argon atmosphere.

Global observation of the results shows that the ceramic contains the three layers described above (Figure 4B), and it could be represented sequentially as in Figure 7. 


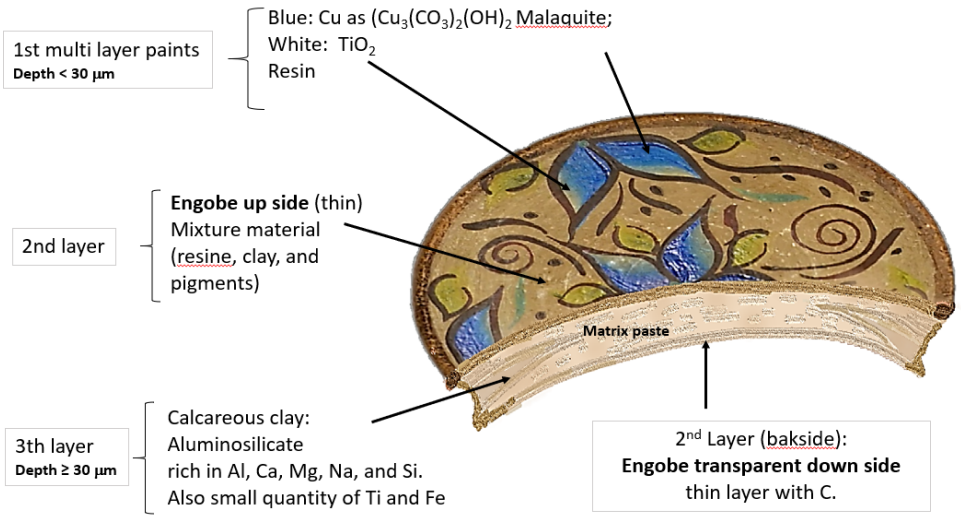

Figure 7. Representation of element composition in the layers.

\section{CONCLUSIONS}

The results of this research allow us to assume that the pottery plate's manufacturing procedure was sequentially matrix paste $->$ engobe $\rightarrow$ white and blue decoration. The elemental composition confirms the presence of malaquite (blue) and $\mathrm{TiO}_{2}$ (white). Though an organic material in this contemporary pottery was confirmed, the analysis of other samples as ancient pottery will need to optimize LIBS parameters for $\mathrm{C}$ detection and find the adequate procedure to eliminate de Fe interference. Otherwise, it would be interesting to use a top-hat beam profile to perform an analysis with a good stratigraphic resolution.

The stratigraphic analysis using LIBS reveals which elements are present in the different thin layers. The $5.6 \mathrm{~mJ}$ laser pulse creates a crater of approximately $60 \mu \mathrm{m}$ on the surface that could be imperceptible by human eye. This minimal destruction could be acceptable in cultural heritage samples or other valuable materials.

\section{ACKNOWLEDGMENTS}

The authors are grateful for the financial support through the Yachayninchis Wiñarinanpaq mobility program of the Vice-Rector for Research of the Universidad Nacional de San Antonio Abad del Cusco. We thank in a special way Professor Jorge Linares and Dr. François Piuzzi for initiating the collaboration between CEA and UNSAAC. 


\section{REFERENCES}

1. Hunault M, Lelong G, Gauthier M, Gélébart F, Ismael S, Galoisy L, et al. Assessment of Transition Element Speciation in Glasses Using a Portable Transmission UltravioletVisible-Near-Infrared (UV-Vis-NIR) Spectrometer. Appl Spectrosc. 2016;70(5):778784.

2. Aramendia J, Gómez-Nubla L, Fdez-Ortiz de Vallejuelo S, Castro K, Arana G, Madariaga JM. The combination of Raman imaging and LIBS for quantification of original and degradation materials in Cultural Heritage. J Raman Spectrosc. 2019; 50(2):193-201.

3. Bahçeli S, Güleç G, Erdoğan H, Söğüt B. Micro-Raman and FT-IR spectroscopic studies of ceramic shards excavated from ancient Stratonikeia city at Eskihisar village in WestSouth Turkey. J Mol Struct. 2016;1106:316-321.

4. Singh P, Mal E, Khare A, Sharma S. A study of archaeological pottery of Northeast India using laser induced breakdown spectroscopy (LIBS). J Cult Herit. 2018; 33:71-82.

5. Zheng L, Wang Z, Shen S, Xia Y, Li Y, Hu D. Blurring of ancient wall paintings caused by binder decay in the pigment layer. Sci Rep. 2020; 10(1):21075. doi: 10.1038/s41598020-78117-4.

6. Bruder R, L'Hermite D, Semerok A, Salmon L, Detalle V. Near-crater discoloration of white lead in wall paintings during laser induced breakdown spectroscopy analysis. Spectrochim Acta Part B At Spectrosc. 2007;62(12):1590-1596.

7. Anglos D, Couris S, Fotakis C. Laser Diagnostics of Painted Artworks: Laser-Induced Breakdown Spectroscopy in Pigment Identification. Appl Spectrosc. 1997; 51(7):10251030.

8. Castillejo M, Martín M, Silva D, Stratoudaki T, Anglos D, Burgio L, et al. Analysis of pigments in polychromes by use of laser induced breakdown spectroscopy and Raman microscopy. J Mol Struct. 2000;550-551:191-198.

9. Anglos D. Laser-Induced Breakdown Spectroscopy in Art and Archaeology. Appl Spectrosc. 2001;55(6):186A-205A.

10. Colao F, Fantoni R, Lazic V, Spizzichino V. Laser-induced breakdown spectroscopy for semi-quantitative and quantitative analyses of artworks - application on multilayered ceramics and copper based alloys. Spectrochim Acta Part B At Spectrosc. 2002; 57(7):1219-1234.

11. Botto A, Campanella B, Legnaioli S, Lezzerini M, Lorenzetti G, Pagnotta S, et al. Applications of laser-induced breakdown spectroscopy in cultural heritage and archaeology: a critical review. J Anal At Spectrom. 2019;34(1):81-103.

12. Lazic V, Trujillo-Vazquez A, Sobral H, Márquez C, Palucci A, Ciaffi M, et al. Corrections for variable plasma parameters in laser induced breakdown spectroscopy: Application on archeological samples. Spectrochim Acta Part B At Spectrosc. 2016; 122:103-13.

13. Kramida A, Olsen, K., Ralchenko, Yu. NIST LIBS Database - Atomic Spectra Database Lines [Internet]. [citado 11 de enero de 2018]. Disponible en: https://physics.nist.gov/ PhysRefData/ASD/lines_form.html

14. IVEA. MOBILIBS IVEA [Internet]. [citado 20 de diciembre de 2020]. Disponible en: http://www.teo.com.cn/filespath/files/20130809110416.pdf

15. IUMTEK Starup Cleantech. IUMTEK real-time analytics [Internet]. iumtek. [citado 6 de marzo de 2021]. Disponible en: https://iumtek.com/ 